\title{
Polar Bear Conservation in Canada: Defining the Policy Problems
}

\author{
DOUGLAS A. CLARK, ${ }^{1,4}$ DAVID S. LEE, ${ }^{2}$ MILTON M.R. FREEMAN ${ }^{3}$ and SUSAN G. CLARK ${ }^{4}$
}

(Received 15 June 2007; accepted in revised form 2 January 2008)

\begin{abstract}
Conservation of polar bears (Ursus maritimus) in Canada is based on the goals and principles of the 1973 International Agreement on the Conservation of Polar Bears and Their Habitat, and has long been considered an exemplar of science-based wildlife management. However, accelerating social and ecological changes in the Arctic raise questions about the polar bear management regime's ability to adapt successfully to new challenges. We apply the analytic framework of the policy sciences to develop a comprehensive orientation to this evolving situation, and we suggest possible ways to define and advance shared goals of stakeholders and other participants. We conclude that the decision process in polar bear management does not sufficiently foster identification and securing of common interests among participants who express multiple, competing perspectives in an arena that has been increasingly fragmented and symbolically charged by issues such as the recent listing of polar bears under the U.S. Endangered Species Act. The fundamental challenge for polar bear conservation in Canada is to design a better decision process so that it can constructively reconcile the various perspectives, demands, and expectations of stakeholders.
\end{abstract}

Key words: Canada, conservation, decision process, Endangered Species Act, Inuit Qaujimajatuqangit, Nunavut, polar bear, policy, policy sciences, traditional ecological knowledge, Ursus maritimus

RÉSUMÉ. Au Canada, la conservation des ours polaires (Ursus maritimus) respecte les objectifs et les principes de l'Accord international sur la conservation des ours blancs et leur habitat de 1973, qui est considéré depuis longtemps comme un modèle de gestion de la faune fondée sur la science. Cependant, l'évolution de plus en plus rapide des changements d'ordre social et écologique dans l'Arctique a pour effet de soulever des questions sur l'aptitude du régime de gestion de l'ours polaire à bien s'adapter aux nouveaux défis. Nous utilisons le cadre de référence analytique de la science des politiques pour aboutir à une orientation exhaustive de cette situation en pleine évolution, et nous suggérons des manières possibles de définir et de formuler des objectifs partagés par les parties prenantes et d'autres participants. Nous concluons que le processus de décision en matière de gestion de l'ours polaire n'encourage pas suffisamment l'identification et l'engagement d'intérêts communs entre les participants qui expriment des perspectives multiples et concurrentes dans un domaine de plus en plus fragmenté et symboliquement caractérisé par des enjeux tels que la liste récente d'ours polaires en vertu de la loi américaine sur les espèces en voie de disparition (U.S. Endangered Species Act). Le défi fondamental en ce qui a trait à la conservation des ours polaires au Canada consiste à concevoir un meilleur processus de décision pouvant réconcilier, de manière constructive, les diverses perspectives, exigences et attentes des parties prenantes.

Mots clés : Canada, conservation, processus de décision, Endangered Species Act, Inuit Qaujimajatuqangit, Nunavut, ours polaire, politique, science des politiques, connaissances écologiques traditionnelles, Ursus maritimus

Traduit pour la revue Arctic par Nicole Giguère.

\section{INTRODUCTION}

In just the past four years, the stable, 30-year-old international system of polar bear (Ursus maritimus) conservation has been profoundly destabilized by controversies over the impacts of climate change and how best to manage bear populations in the face of those impacts. Resolution of these controversies, if indeed even possible, will require comprehensive, interdisciplinary, and sensitive crosscultural analysis of a complex and still-unfolding policy process that is now highly politicized (Watt-Cloutier,
2007). Fortunately, there are techniques for such analyses that have proven to be effective at addressing conservation conflicts involving diverse species, ranging from grizzly bears (Ursus arctos) and wolves (Canis lupus) (Clark et al., 2005), to elk (Cervus elaphus) (Clark et al., 2000a), koalas (Phascolarctos cinereus) (Clark et al., 2000b), and eastern barred bandicoots (Perameles gunnii) (Clark et al., 1995). We apply those techniques to gain insight into the evolving problems of polar bear conservation in Canada.

A useful starting point in such an analysis is to consider the goals of polar bear conservation efforts to date. Conservation

\footnotetext{
${ }^{1}$ Department of Renewable Resources, University of Alberta, Edmonton, Alberta T6G 2E1, and Northern Research Institute, Yukon College, PO Box 2799, Whitehorse, Yukon Y1A 5K4, Canada; daclark@ales.ualberta.ca

${ }^{2}$ Nunavut Tunngavik Inc., Rankin Inlet, Nunavut X0C 0G0, Canada

${ }^{3}$ Canadian Circumpolar Institute, University of Alberta, Edmonton, Alberta T6G 0H1, Canada

${ }^{4}$ Yale School of Forestry and Environmental Studies, New Haven, Connecticut 06511-2189, USA

(C) The Arctic Institute of North America
} 
of polar bears both in Canada and internationally has long been considered a success story in wildlife management (Fikkan et al., 1993; Prestrud and Stirling, 1994; Ross, 2000). Conservation measures for polar bears in Canada have generally been based on the goals and principles of the 1973 International Agreement on the Conservation of Polar Bears and Their Habitat (hereafter, the Agreement; Stirling, 1988). These measures are implemented by provincial and territorial governments, along with aboriginal co-management organizations, through a coordinated, cross-scale, institutional network (Berkes et al., 2005). The Agreement provides for protection of polar bear habitat and populations, and thus is a strong statement of conservation goals established in the public interest (Appendix 1). The Agreement also provides for signatory countries to permit the harvest of polar bears by local and aboriginal people exercising traditional rights. These themes of conservation and consumptive use of wildlife are also evident in aboriginal land-claim settlements in the Canadian Arctic such as the 1984 Inuvialuit Final Agreement (INAC, 1984) and the 1993 Nunavut Final Agreement (INAC and Tungavik Federation of Nunavut, 1993). Within Canada, therefore, polar bear conservation with provision for co-managed harvesting regimes has become an established and widely shared policy goal.

However, recent events are raising concerns about the Canadian polar bear management system and whether the goals set out in the Agreement are being achieved. Competing perspectives on contentious matters such as the impacts of climate change and hunting have recently emerged and have become the bases for public conflicts (e.g., PBSG, 2005; Dowsley and Wenzel, 2008). Such a confrontational situation can significantly reduce the effectiveness of large carnivore conservation efforts (Rutherford and Clark, 2005). Moreover, if co-management regimes cannot reconcile conflicting demands rooted in competing perspectives, even "best practice" conservation initiatives based on considerable scientific research can collapse (Clark and Slocombe, 2005). The Arctic is experiencing some of the most rapid social and ecological changes on earth (ACIA, 2004; AHDR, 2004), and questions have been raised about the ability of current Canadian polar bear management systems to adapt to various social and ecological changes (Derocher et al., 2004; Berkes et al., 2005; Diduck et al., 2005). For example, aboriginal land-claim settlement has fundamentally altered the relationships among organizations that manage polar bears (Berkes et al., 2005), and rapidly changing weather patterns and shifting boundaries of bear populations could make current bear research methods much more costly, or even infeasible (Derocher et al., 2004).

The current science-based polar bear co-management regime could fall short of conservation goals if it cannot effectively resolve emerging conflicts among stakeholders in a dignified manner. Wildlife management regimes that fail to foster human dignity-equitable access to allimportant human values (Lasswell and McDougal, 1992) _ through the civil pursuit of common interest outcomes also often fail at their primary conservation objectives (Brunner et al., 2005; Clark, 2007). Our goal in this paper is to provide a comprehensive orientation to the evolving situation of polar bear management as a basis for recommending measures that could help participants define and achieve their common interests. Ultimately we hope that this analysis will stimulate a more constructive, less divisive dialogue about polar bear conservation.

\section{METHODS}

This paper applies the interdisciplinary problemsolving framework of the policy sciences (Clark, 2002) to current polar bear conservation efforts and institutions in Canada. This field of inquiry employs knowledge of the policy process to achieve insight into the process itself, including the deployment of knowledge by participants (Lasswell, 1970, 1971). Broadly defined, the policy process is the aggregate set of decisions made by all participants directly or indirectly involved in a specific issue, as well as the outcomes and effects of those decisions. In this case, the policy process includes the entire interrelated set of federal, territorial, provincial, and local decisions made about polar bears, including setting and administering both harvest quotas and parameters for bear-viewing tourism operations, hunting bears, planning and conducting research, managing bear-human conflicts, and adjusting the processes whereby these and other such decisions are made.

Problem orientation in the policy sciences is an analytical exercise involving five distinct tasks: clarifying goals, describing trends, analyzing conditions, projecting developments, and inventing, evaluating, and selecting alternatives (Lasswell, 1971). These tasks should be carried out interactively and iteratively, informed by what is known about the context of a specific problem rather than by a priori theoretical or ideological frames (Clark, 2002). Our analysis, beginning with the above discussion of the 1973 Agreement goals, constitutes a preliminary orientation to the problems of the current polar bear policy process in Canada.

We base our analysis on published literature, minutes of meetings by key management organizations, institutional documents, and a comprehensive survey of major Canadian media sources for print articles and editorials on polar bear management in Canada from December 2004 to June 2007. These included CBC North $(\mathrm{n}=38)$, the Globe and Mail $(\mathrm{n}=8)$, and Nunatsiaq News $(\mathrm{n}=6)$. These diverse sources of information were compared and contrasted in order to create our provisional descriptions of the social and decision processes operative here, and also to increase the reliability and internal validity of our conclusions about this specific case (Yin, 2003). Our analysis is also informed by personal experience: three of the authors have approximately 73 years of combined experience in 
wildlife research and management across the Canadian North, and two of the authors have served on the FederalProvincial-Territorial Polar Bear Technical Committee.

\section{RESULTS}

\section{Social and Ecological Trends, Conditions, and Projected Developments}

In Canada polar bears are managed by a network of government agencies, academic researchers, and aboriginal governments and land-claim organizations. Two interagency groups provide the strong institutional linkages that comprise this network: the Federal-ProvincialTerritorial Polar Bear Technical Committee (PBTC), and the Federal-Provincial-Territorial Polar Bear Administrative Committee (PBAC). These cross-scale institutions are vertically structured as a hierarchy (the PBTC makes recommendations to the $\mathrm{PBAC}$ ), and though they have grown to include co-management organizations, their discourse remains overwhelmingly that of science-based wildlife conservation (Berkes et al., 2005). Canadian polar bear biologists and managers are also well represented on the World Conservation Union (IUCN) Polar Bear Specialist Group (PBSG). Following many relatively stable years of coordinated research and science-based management (Prestrud and Stirling, 1994), emergent social and ecological changes in the Arctic have pushed the Canadian polar bear management regime into a state of flux. The full effects of these changes are not yet apparent, as they are ongoing and are also interlinked with other evolving situations and decision processes.

Co-management regimes have arisen from the settlement of aboriginal land claims throughout northern Canada, changing the distribution of power in wildlife management systems (Nadasdy, 2003; Armitage and Clark, 2005) and introducing traditional ecological knowledge (TEK) as a basis for decision making, alongside science (Berkes, 1999; Treseder et al., 1999; Watson et al., 2003; Menzies, 2006). This transition has been a turbulent process not wholly welcomed by the scientific and non-aboriginal managerial communities (Howard and Widdowson, 1996; Gilchrist et al., 2005), whose roles are themselves the subject of much recent critique (e.g., Nadasdy, 2003; Natcher et al., 2005; Brook and McLachlan, 2005; Stevenson, 2006; White, 2006). In the case of polar bear management, this trend has led not only to the groundbreaking 1988 Inuvialuit-Inupiat Polar Bear Management Agreement (Brower et al., 2002; Johnson, 2002), but also to one of the most contentious recent decisions about polar bear management. In December 2004, Nunavut's Minister of Renewable Resources announced that harvest quotas for six polar bear populations would be increased, in some cases substantially, based on Inuit Qaujimajatuqangit (IQ) - a concept that can broadly be considered as the contextual, traditional knowledge of Inuit (Wenzel, 2004).
Significantly, one of the populations whose quota was raised (and then later reduced) was the Western Hudson Bay population, which has been studied extensively since the late 1960s and has furnished the clearest scientific evidence so far for negative impacts of climate change on polar bears (Stirling et al., 1999; Stirling and Parkinson, 2006; Regehr et al., 2007). The quota increase was criticized heavily by individual biologists and environmental groups in the media (below), and was followed within months by the PBSG's Resolution Number One, "A precautionary approach when setting catch levels in a warming Arctic," which recommended "that polar bear harvests can be increased on the basis of local and traditional knowledge only if [that knowledge is] supported by scientifically collected information" (PBSG, 2005:57).

Recent global-scale climate assessments have shown a considerable decrease in Arctic sea ice, which is projected to continue, likely leading to a seasonally ice-free Arctic Ocean within this century (ACIA, 2004; Overpeck et al., 2005; Holland et al., 2006; IPCC, 2007). Ecological studies have provided strong evidence that polar bears are vulnerable to the effects of climate change in the Arctic (Stirling and Derocher, 1993; Stirling et al., 1999; Derocher et al., 2004; Amstrup et al., 2006; Stirling and Parkinson, 2006; Regehr et al., 2007). Polar bears are found throughout the ice-covered Arctic seas and are specialized predators on ice-dependent seals. Ringed seals (Phoca hispida) and bearded seals (Erignathus barbatus) form the majority of the bears' diet in most of their range (DeMaster and Stirling, 1981). Reductions in sea-ice extent or duration due to a warming Arctic climate thus have the potential for profound negative impacts on polar bear populations (Stirling and Derocher, 1993). Longitudinal research in western Hudson Bay demonstrated that earlier sea-ice breakup reduced the body condition of female polar bears, leading to decreased cub survival (Stirling et al., 1999) and an apparent decline in overall population size (Regehr et al., 2007). Similar studies in the Beaufort Sea have linked a decrease in sea ice to a reduction in body condition and cub survival there as well (Regehr et al., 2006). Nutritional stress from reduced access to sea ice may also lead polar bears to seek out human foods, increasing the likelihood of bear mortalities and human injuries (Stirling and Derocher, 1993; Clark, 2003). Although polar bears are capable of living with only seasonal sea ice if it is of sufficient duration and prey species are present, their overall range will likely be drastically reduced and specific populations will decline or even become extirpated, although other populations may benefit from increased marine productivity, at least in the short term (Stirling and Derocher, 1993; Stirling and Parkinson, 2006).

Consequently, polar bears have become a prominent symbol in efforts to combat global climate change. One such effort was the 2005 petition by three environmental organizations to list the polar bear under the U.S. Endangered Species Act (ESA) (Center for Biological Diversity, 2005). In 2006, the U.S. Fish and Wildlife Service 
recommended listing polar bears as a threatened species throughout their range because of the observed and projected impacts of a warming climate on Arctic sea ice (USFWS, 2007), and the recommendation was implemented on 14 May 2008 (USFWS, 2008). The listing has caused considerable concern for territorial wildlife managers and Inuit communities and organizations, who fear that a ban on importation of hunt trophies to the United States would threaten the market for sport hunts. The Center for Biological Diversity stated that its intention in seeking a listing was to compel the U.S. government to take action to reduce greenhouse gas emissions, and not to harm Inuit livelihoods (CBC, 2006). Nevertheless, importing polar bear parts to the United States was prohibited under that listing.

For Inuit, there is precedent for such fears. The international seal hunt protests of the 1970s and 1980s, although largely focused on the Gulf of St. Lawrence, led to a ban on sealskin imports by the European Economic Community and had profound negative impacts on economies and livelihoods in Inuit communities (Wenzel, 1991; Young, 1992). Polar bears are important to Inuit and Inuvialuit people not only because they are hunted for subsistence, but also because the guiding of sport hunters (predominantly Americans) generates considerable economic activity in their remote communities and sustains cultural traditions (Keith et al., 2005; Freeman and Wenzel, 2006). The term "conservation hunting" has been applied to this situation because it has produced a regulated and sustainable management regime for the species as well as local social and economic benefits (Freeman and Wenzel, 2006).

Projecting current trends and conditions is admittedly risky in a complex social-ecological system such as the relationship between people and polar bears in the Arctic. The impacts of climate change on both polar bear populations and the human activities related to polar bears will likely be highly variable, both spatially and temporally (Derocher et al., 2004). Efforts to forecast the status of those populations beyond a few years are therefore unlikely to be accurate (Berteaux et al., 2006; Krebs and Berteaux, 2006). Nevertheless, even simplistic, short-term projections suggest plausible scenarios in which continued loss of sea ice will seriously affect some polar bear populations, especially those that already cope with icefree summers, and increase the likelihood of polar bearhuman conflicts. Under such circumstances, the scientific and conservation communities will exert considerable pressure in Canada and internationally to reduce quotas, and Nunavut communities are likely to resent those efforts (Ford et al., 2007; Tyrrell, 2007). This resentment could cause less tolerance for bears and therefore more dead bears during conflict situations. An excessive number of bears shot in defense of life or property could negate any hunting quota reductions.

Existing cross-scale institutional connections that tend to marginalize aboriginal interests could make the situation even worse. Now that polar bears have been listed under the U.S. ESA, and the U.S. Fish and Wildlife Service has restricted sport hunt trophy imports (USFWS, 2008), economic benefits to the Inuit and Inuvialuit from existing hunting programs may be much reduced. This outcome may very well diminish their willingness to collaborate with non-aboriginal managers and conservationists (State of Alaska, 2007). The national and international media attention that increasingly accompanies any polar bear issue would predictably exacerbate any conflicts, eroding civility and hardening participant perspectives. Moderate and nuanced positions, such as that articulated by the U.S. Marine Mammal Commission, which supported listing while also recognizing the conservation benefits of allowing continued importation of polar bear hunt trophies (Marine Mammal Commission, 2007), will find themselves stranded on a shrinking middle ground. Under such circumstances, finding common ground could be virtually impossible short of a severe crisis.

\section{DISCUSSION}

We identified three conditions in the aggregate polar bear policy process in Canada that, together, create outcomes not only potentially compromising to polar bear conservation, but also, as our results suggest, likely to be detrimental to the dignity of people involved. Two of these conditions-multiple competing perspectives and fragmented, divisive social process - are not intrinsically problematic, but when coupled with decision-making processes that polarize rather than bring together the participants, the outcomes are fundamentally destructive to civil society.

\section{Condition 1: Multiple Competing Perspectives}

The main perspectives advanced so far by participants in polar bear management are rooted in myths: the structured narratives that inform individuals' mental models of the world around them (Table 1). Here, the term "myth" is analogous to concepts such as discourse, narrative, or worldview, rather than denoting simply a fictional story (Clark, 2002). The key elements of myth, including doctrine (core beliefs), formula (preferred ways of acting to achieve doctrinal outcomes), and miranda (symbols that manifest core beliefs), provide insight into perspectives that shape positions advocated by those involved in polar bear management. In fact, much of the public polarization and confrontation over polar bears can be explained by the myths that underlie the perspectives of key participants.

Perspective 1. "The polar bears are drowning": The doctrinal premise of this perspective is that anthropogenic global warming is reducing the sea ice on which polar bears depend for their survival, and they will shortly become extinct without intervention. This perspective is a specific version of the archetypal environmentalist discourse of "survivalism"; the idea that the Earth has finite limits, and that crossing those limits means inexorable ecological and human disaster on a global scale (Dryzek, 
TABLE 1. Perspectives prevalent in the polar bear case, and components of their associated myths.

\begin{tabular}{|c|c|c|c|}
\hline Perspective & Doctrine & Formula & Miranda (symbols) \\
\hline "The polar bears are drowning" & $\begin{array}{l}\text { Human actions must not exceed the Earth's } \\
\text { finite limits (survivalism discourse). } \\
\text { Anthropogenic global warming is reducing the } \\
\text { sea ice on which polar bears depend for their } \\
\text { survival. }\end{array}$ & $\begin{array}{l}\text { Governments must act to limit } \\
\text { greenhouse gas emissions, } \\
\text { protect polar bears and stop } \\
\text { global warming. }\end{array}$ & $\begin{array}{l}\text { Polar bears are a powerful } \\
\text { symbol to motivate } \\
\text { governmental action on } \\
\text { climate change. }\end{array}$ \\
\hline "Scientific management is necessary" & $\begin{array}{l}\text { Empirical biological studies revealed the } \\
\text { impacts of climate change on polar bears and } \\
\text { are necessary for informed decision-making } \\
\text { (administrative rationalism discourse). } \\
\text { Inuit beliefs about there being more bears } \\
\text { are wrong. }\end{array}$ & $\begin{array}{l}\text { Good science will continue to } \\
\text { inform expert decision-makers } \\
\text { and should be the deciding factor } \\
\text { in conservation decisions. } \\
\text { The precautionary principle is } \\
\text { appropriate. }\end{array}$ & $\begin{array}{l}\text { The } 1973 \text { Agreement is a } \\
\text { symbol of conservation } \\
\text { success and international } \\
\text { cooperation. }\end{array}$ \\
\hline "Listen to us - we see more bears now' & $\begin{array}{l}\text { Inuit know how to co-exist with polar bears. } \\
\text { In some areas Inuit see more bears now than } \\
\text { ever and they are more aggressive. } \\
\text { The scientists are wrong about population } \\
\text { declines. }\end{array}$ & $\begin{array}{l}\text { IQ needs to be used in making } \\
\text { decisions, especially restrictive } \\
\text { harvest quotas that limit how } \\
\text { people can respond to threats } \\
\text { from bear encounters. }\end{array}$ & $\begin{array}{l}\text { Polar bears are now a greater } \\
\text { danger to human safety than } \\
\text { they used to be. Inuit } \\
\text { communities are victims of } \\
\text { misguided protection efforts. }\end{array}$ \\
\hline "There is no problem" & $\begin{array}{l}\text { Human ingenuity and new technology will } \\
\text { solve any environmental problems. } \\
\text { There are no intrinsic ecological limits on } \\
\text { human activities (Promethean discourse). }\end{array}$ & $\begin{array}{l}\text { Selective use of intelligence and } \\
\text { promotion of uncertainty in the } \\
\text { public's mind, reducing the } \\
\text { perceived urgency of action on } \\
\text { climate change. }\end{array}$ & $\begin{array}{l}\text { Scientists who dissent from } \\
\text { consensuses are used as } \\
\text { symbols to illustrate scientific } \\
\text { uncertainty about climate } \\
\text { change. }\end{array}$ \\
\hline
\end{tabular}

1997). The legitimized formula is thus one that calls for massive and immediate action by governments-informed by scientists and elites-to stop mankind from crossing those limits; which in this case are tangibly defined as greenhouse gas emissions. According to this perspective, polar bears are not only indicators of climate change impacts, but also powerful symbols for mobilizing public interest and pressuring governments to act on climate change: more so perhaps than other species which may be equally affected but less charismatic, such as Kittlitz's murrelet (Brachyramphus brevirostris) (Siegel, 2007).

Perspective 2. "Scientific management is necessary": This perspective is similar to the first in asserting that climate change is affecting polar bears, but is usually framed in more cautious and less alarmist language. Nonetheless, it differs in both degree and emphasis on what needs to be done to address those impacts. This perspective fits more closely with the doctrine and formula of Dryzek's (1997) "administrative rationalism" discourse, in which experts acting in the public interest are best suited to identify and solve problems. Scientists in Canada and elsewhere have consistently been successful using the 1973 Agreement as a symbol of international cooperation to leverage national government support for research programs (Prestrud and Stirling, 1994). The formula of this myth prescribes more of the same: the continuation of expert-driven, hierarchical, and bureaucratic "scientific management."

Scientific management is the widespread approach of using science as the foundation for policies made through a central bureaucratic authority (Brunner et al., 2005), and its emergent weaknesses are well documented (Ludwig et al., 1993; Holling and Meffe, 1996; Ludwig, 2001; Brunner et al., 2005). The heart of this doctrine goes back to the
Enlightenment, but it was reinforced during the Progressive Era of the last century, when it was designed into the very fabric of most natural resources management institutions (Brunner et al., 2005). The privileged place of technical experts in this myth may predispose scientists to publicly discredit and disbelieve Inuit claims that polar bear populations have increased in some localities-a potentially inflammatory position, given the current importance placed on traditional knowledge in northern resource management.

Perspective 3. "Listen to us-we see more bears now": Inuit communities in several regions of Nunavut, particularly western Hudson Bay and Baffin Bay, report that they have been seeing more polar bears in recent years than ever before, and that the bears are coming into communities and acting more aggressively (Tyrrell, 2007). The doctrine that shapes how Inuit interpret these observations is Inuit Qaujimajatuqangit (IQ) (Wenzel, 2004). Current observations are contextualized through comparison with past conditions (more bears are being observed and their behaviour is different compared to the past), and established norms and customs provide the formula for how to deal with the situation. The existing harvest quota system is seen as a barrier to re-establishing appropriate human behaviours towards polar bears, and it limits how local communities can respond to threats from bears (Tyrrell, 2007). To the Inuit, polar bears are coming to symbolize their vulnerability to outside imposition of protection efforts whose validity is questionable, and IQ deserves a more prominent place in decision-making. Interestingly, this myth does not fit any of Dryzek's (1997) typology of environmental discourses.

Perspective 4. "There is no problem": The very existence of climate change, let alone its categorization as a 
"problem" affecting polar bears, has been extensively challenged in the public arena. Such challenges come from adherents to a "Promethean" doctrine of infinite economic growth, resilient nature, and faith in human ingenuity and technology to overcome limits; a perspective particularly resonant with neo-conservative philosophies in the United States (Dryzek, 1997). Indeed, much of the non-Inuit criticism of scientists' claims of impacts on polar bears comes from established climate change skeptics in the United States. The formula of this myth entails claims about substantial scientific uncertainty and ambiguity (Monbiot, 2006), as well as selective use of intelligence to counter claims about climate change (Inhofe, 2006) and its impacts on polar bears. Scientists who disagree with the prevailing consensus - for whatever reasons - are held up as symbols to demonstrate the existence of scientific uncertainty (e.g., Foote, 2007) and furthermore suggest that hidden environmental agendas are at play that the public ought to react against (Inhofe, 2006).

However, it is important to note that legitimate scientific skepticism does exist about specific relationships between human activities, a warming Arctic climate, sea ice, and polar bears (Dyck et al., 2007). Such dissent is a normal and healthy part of scientific discourse, and entirely expected given the social and biophysical complexity of the issue at hand. Such skepticism should be carefully differentiated from the broader narrative of climate change denial, although this is a task that may be easier said than done. These critiques aren't yet sufficiently comprehensive to form a fifth perspective on this specific issue, but they may very well become the nucleus of a new narrative in the future.

\section{Condition 2: Insufficient Performance of Decision Processes}

The decision process is the collective set of decisions made by all participants, differentiated as pertaining to seven different functions (Lasswell, 1971). These are: 1. intelligence (gathering, processing, and disseminating information), 2. promotion (articulating and intensifying specific demands), 3. prescription (stabilizing expectations or norms, with respect to a particular perspective or alternative), 4. invocation (initially characterizing a concrete situation and required actions), 5. application (finally characterizing a concrete situation and required actions), 6. appraisal (evaluating decisions according to achievement of goals, identifying responsibility for successes or failures), and 7. termination (canceling a prescribed course of actions and related choices, policies, and institutions). Standards exist for appraising the quality of decision processes (Lasswell, 1971), and many of those standards appear to be at issue for specific decision functions concerning polar bears (below). We define the decision process broadly for polar bears to include the entire suite of decisions across institutions, from communities to the federal government, and by the cross-scale institutions that coordinate them (PBTC and PBAC). Within this aggregate process, individual decision processes, such as those focused on particular bear populations or topics (e.g., polar bear tourism), could be productively examined in detail in future analyses.

So far, the decision process affecting polar bear management in Canada has apparently not satisfied the interests of many participants. Table 2 presents a set of representative quotes illustrating participants' views of various functions of the decision process, largely dealing with the quota adjustment in Nunavut, the IUCN listing, and the recent ESA listing. Opinions come from across the scale of institutions; regional (Kivalliq Wildlife Board), territorial (Government of Nunavut, Nunavut Tunngavik Inc.), national (Inuit Tapiriit Kanatami, Canadian Wildlife Service), and international (the PBSG, World Wildlife Fund, Inuit Circumpolar Conference). Perhaps the most telling feature of these quotes is that none of them indicate satisfaction with the functioning of the aggregate decision process. In our review of media coverage, the only positive comments about any decision functions came from Nunavut politicians defending quota increases. The decision functions featured most often in Table 2 are formative stages: prescription (8 instances), intelligence (6 instances), and promotion (5 instances). Taken together, the comments paint a picture of decision functions that neither include all participants nor reflect their diverse perspectives, and in which intelligence is vigorously contested.

Indeed, disagreement over intelligence is represented by participants as central to the issue. Nevertheless, neither the quantity nor the quality of currently available scientific information seems to be helping those involved in polar bear management to find common ground. This state of affairs contravenes conventional assumptions of scientific management (Brunner et al., 2005) and administrative rationalism expressed in perspective 2. However, such situations are common in natural resource management (Healy and Ascher, 1995), so it would be naïve to expect that simply more or better intelligence of any sort will, by itself, resolve conflict and disagreements. Intelligence is being used selectively to promote different perspectives, raising questions about the comprehensiveness, dependability, and openness of intelligence processes.

Here, science and traditional knowledge are both promoted as dependable sources of information, each often to the exclusion of the other. Scientists in effect discredit IQ through presentations of their research, and are in turn disbelieved by Inuit community members and their representatives (Table 2). Much detail is lost in this unfortunate polarization, not only about the mutually admitted strengths of each body of knowledge, but also about their respective limitations. For instance, legitimate questions about the methods and quality of Nunavut's IQ consultations on polar bears appear not to have been satisfactorily addressed (George, 2005). A measure of transparency, among other attributes, is important for generating credibility and acceptance of such investigations (Nadasdy, 2006). 
TABLE 2. Public comments on recent decision-making in polar bear conservation.

\begin{tabular}{|c|c|c|c|c|}
\hline Perspective and Source & $\begin{array}{l}\text { Decision } \\
\text { function(s) }\end{array}$ & Standards at issue & $\begin{array}{l}\text { Base and scope } \\
\text { values invoked }\end{array}$ & $\begin{array}{l}\text { Procedural or } \\
\text { content-oriented? }\end{array}$ \\
\hline $\begin{array}{l}\text { "IQ is understood and accepted in Nunavut, but it's not } \\
\text { understood and accepted across Canada and the world." Mitch } \\
\text { Taylor, Gov't. of Nunavut, Nunatsiaq News, } 16 \text { April } 2004\end{array}$ & Intelligence & $\begin{array}{l}\text { Dependability, } \\
\text { Selectivity }\end{array}$ & $\begin{array}{l}\text { Respect, } \\
\text { Enlightenment }\end{array}$ & $\begin{array}{l}\text { Content - a statement about } \\
\text { the content of polar bear } \\
\text { conservation decisions (here, } \\
\text { information inputs) }\end{array}$ \\
\hline $\begin{array}{l}\text { "... I understand the aim of blending IQ and science } \\
\text { information but I would really want to make sure that the } \\
\text { story was the same from both fronts before really agreeing } \\
\text { that substantial increase was merited." Peter Ewins, World } \\
\text { Wildlife Fund Canada, CBC North, } 18 \text { January } 2005 \text {. }\end{array}$ & Promotion & Rationality & Rectitude & $\begin{array}{l}\text { Content, in terms of what } \\
\text { information inputs are } \\
\text { necessary, but has procedural } \\
\text { implications (privileging } \\
\text { certain participants) }\end{array}$ \\
\hline $\begin{array}{l}\text { "When you see more bears, that doesn't mean that there are } \\
\text { more bears." Nick Lunn, Canadian Wildlife Service, CBC } \\
\text { North, } 18 \text { February } 2005 \text {. }\end{array}$ & Intelligence & $\begin{array}{l}\text { Dependability, } \\
\text { Rationality }\end{array}$ & Enlightenment & Content \\
\hline \multirow{4}{*}{$\begin{array}{l}\text { "...Recommends that polar bear harvests can be increased on } \\
\text { the basis of local and traditional knowledge only if supported } \\
\text { by scientifically collected information." IUCN Polar Bear } \\
\text { Specialists Group, Resolutions, } 2005 \text {. }\end{array}$} & Intelligence & $\begin{array}{l}\text { Comprehensiveness, } \\
\text { Selectivity }\end{array}$ & $\begin{array}{l}\text { Power (framed as } \\
\text { Enlightenment) }\end{array}$ & $\begin{array}{l}\text { Procedural - a statement on } \\
\text { how polar bear conservation } \\
\text { decisions should be made }\end{array}$ \\
\hline & Promotion & $\begin{array}{l}\text { Rationality, } \\
\text { Integrativeness, } \\
\text { Comprehensiveness }\end{array}$ & & \\
\hline & Prescription & $\begin{array}{l}\text { Rationality, } \\
\text { Inclusiveness, } \\
\text { Effectiveness }\end{array}$ & & \\
\hline & Invocation & $\begin{array}{l}\text { Non-Provocativeness, } \\
\text { Rationality, } \\
\text { Common Interest, } \\
\text { Dependability }\end{array}$ & & \\
\hline $\begin{array}{l}\text { "It's going to be tough. They (the HTOs) were kind of happy } \\
\text { when they had the increase, now they're sort of turned } \\
\text { down... so I don't know what kind of reaction they'll have } \\
\text { but they're not going to be happy about it." David Aksawnee, } \\
\text { Kivalliq Wildlife Board, Nunatsiaq News, } 9 \text { June } 2005 \text {. }\end{array}$ & Prescription & $\begin{array}{l}\text { Inclusiveness, } \\
\text { Effectiveness }\end{array}$ & $\begin{array}{l}\text { Affection, } \\
\text { Well-Being }\end{array}$ & Content \\
\hline $\begin{array}{l}\text { "I hope the communities will accept all the information and } \\
\text { reduce the quotas to levels that are sustainable at the } \\
\text { moment..." Ian Stirling, Canadian Wildlife Service, } \\
\text { Nunatsiaq News, } 9 \text { June } 2005 \text {. }\end{array}$ & Promotion & $\begin{array}{l}\text { Integrativeness, } \\
\text { Comprehensiveness } \\
\text { Inclusiveness, } \\
\text { Effectiveness }\end{array}$ & $\begin{array}{l}\text { Rectitude, } \\
\text { Enlightenment }\end{array}$ & Content \\
\hline $\begin{array}{l}\text { On the documentation of IQ to support the Nunavut } \\
\text { government's quota increases: "Specific questions and } \\
\text { responses were not systematically recorded during the } \\
\text { consultations." Jo-Anne Falkiner, Access to Information Act } \\
\text { Coordinator for Nunavut, Nunatsiaq News, } 5 \text { August } 2005 \text {. }\end{array}$ & Intelligence & $\begin{array}{l}\text { Dependability, } \\
\text { Comprehensiveness, } \\
\text { Selectivity, Openness }\end{array}$ & $\begin{array}{l}\text { Enlightenment, } \\
\text { Rectitude }\end{array}$ & Content \\
\hline \multirow{2}{*}{$\begin{array}{l}\text { "You need to advise the Canadian Wildlife Service... that } \\
\text { they do a proper job in respecting elders and the advice of } \\
\text { elders." Tagak Curley, Rankin Inlet North MLA, Nunavut, } \\
\text { CBC North, } 21 \text { November } 2005\end{array}$} & Intelligence & $\begin{array}{l}\text { Comprehensiveness, } \\
\text { Selectivity, } \\
\text { Dependability }\end{array}$ & Respect, Rectitude & Procedural \\
\hline & Prescription & $\begin{array}{l}\text { Rationality, } \\
\text { Inclusiveness }\end{array}$ & & \\
\hline $\begin{array}{l}\text { "It feels really bad and you can probably imagine how we felt } \\
\text { when that kind of decision (the IUCN listing) actually affects } \\
\text { Inuit in Canada." Jose Kusugak, Inuit Tapiriit Kanatami, } \\
\text { CBC North, } 12 \text { May } 2006 \text {. }\end{array}$ & Invocation & $\begin{array}{l}\text { Inclusiveness, } \\
\text { Effectiveness } \\
\text { Constructiveness }\end{array}$ & $\begin{array}{l}\text { Well-Being, } \\
\text { Affection }\end{array}$ & $\begin{array}{l}\text { Procedural-invoking } \\
\text { normative standards for } \\
\text { decisions }\end{array}$ \\
\hline $\begin{array}{l}\text { "When organizations make decisions based on predictions } \\
\text { and without fully considering all the facts, it has a seriously } \\
\text { negative impact on Inuit. Harvesting polar bears is an } \\
\text { important part of our culture. The IUCN's decision to list } \\
\text { these animals as vulnerable just because they've changed } \\
\text { their definitions and because of what they think might happen } \\
\text { five decades from now does not make sense." Raymond } \\
\text { Ningeocheak, Nunavut Tunngavik Inc., CBC North, } \\
15 \text { May } 2006 \text {. }\end{array}$ & Invocation & $\begin{array}{l}\text { Inclusiveness, } \\
\text { Effectiveness } \\
\text { Constructiveness }\end{array}$ & Well-Being & $\begin{array}{l}\text { Procedural-invoking } \\
\text { normative standards for } \\
\text { decisions }\end{array}$ \\
\hline
\end{tabular}


TABLE 2. Public comments on recent decision-making in polar bear conservation. - continued

\begin{tabular}{|c|c|c|c|c|}
\hline Perspective and Source & $\begin{array}{l}\text { Decision } \\
\text { function(s) }\end{array}$ & Standards at issue & $\begin{array}{l}\text { Base and scope } \\
\text { values invoked }\end{array}$ & $\begin{array}{l}\text { Procedural or } \\
\text { content-oriented? }\end{array}$ \\
\hline $\begin{array}{l}\text { "There's a lot of uninformed people and these people feed on } \\
\text { the ignorance of these peoples and force governments to } \\
\text { make...policies that are very reactive or very hard on the } \\
\text { people of Nunavut." Patterk Netser, Nunavut Environment } \\
\text { Minister, CBC North, } 2 \text { January } 2007 \text {. }\end{array}$ & $\begin{array}{l}\text { Promotion } \\
\text { Prescription }\end{array}$ & $\begin{array}{l}\text { Rationality, } \\
\text { Authority Signature }\end{array}$ & $\begin{array}{l}\text { Respect, Well-Being, } \\
\text { Rectitude }\end{array}$ & Procedural \\
\hline $\begin{array}{l}\text { "... I am worried that if we remain focused on the smaller } \\
\text { picture, playing smaller politics where we only focus on the } \\
\text { numbers issue in terms of polar bear populations, we will } \\
\text { lose, and lose big. The rhetoric we hear today, our hunter's } \\
\text { observations versus science, journalists weighing in about } \\
\text { science and traditional knowledge, and many more well- } \\
\text { meaning individuals with their own take on this extremely } \\
\text { critical matter, is adding to the confusion.” Sheila Watt- } \\
\text { Cloutier, Inuit Circumpolar Conference and } 2007 \text { Nobel } \\
\text { Peace Prize nominee, Nunatsiaq News, } 19 \text { January } 2007 .\end{array}$ & $\begin{array}{l}\text { Prescription } \\
\text { Intelligence } \\
\text { Promotion }\end{array}$ & $\begin{array}{l}\text { Dependability, } \\
\text { Rationality, } \\
\text { Practicality }\end{array}$ & $\begin{array}{l}\text { Rectitude, } \\
\text { Enlightenment, } \\
\text { Well-Being, } \\
\text { Respect }\end{array}$ & $\begin{array}{l}\text { Procedural - strategic and } \\
\text { critical evaluation of the } \\
\text { unfolding decision process }\end{array}$ \\
\hline
\end{tabular}

Conversely, quantitative studies on polar bear populations in western Hudson Bay (Stirling and Parkinson, 2006; Regehr et al., 2007) assert that contrary to what Inuit say, increased local observations of polar bears entering communities are not due to increased bear populations. Reconciling contrasting scientific and community-based observations is a challenging task, and is complicated by (among other things), differing languages, worldviews, and cultural understandings of basic concepts. Consequently, it is incumbent upon scientists who evaluate local observations to make substantial efforts to ensure that they fully understand the social and cultural context of local experts' statements, especially when those statements conflict with their own conclusions. Neither paper adequately demonstrates that steps were taken to ensure accurate and contextual understanding of what Inuit actually observed and said. Even a simple qualitative validation (Miles and Huberman, 1994) would add considerably to the weight of those scientific arguments, not to mention local acceptance of them. Such an effort might even reveal other factors worth investigating further, which is precisely the sort of outcome that can result from constructive integration of these different knowledge sets (e.g., Manseau et al., 2005; Turner and Clifton, 2006). At present, however, the overall situation is a stalemate, consistent with similar tensions between promoters of TEK and science documented elsewhere (e.g., Berkes, 1999; Menzies, 2006; Stevenson, 2006).

Further, advocates of different political positions selectively quote both published science and individual scientists. For example, U.S. senator James Inhofe in speeches has repeatedly quoted a Nunavut biologist to support the contention that polar bears are not endangered. He mentioned this biologist alone, and no other biologist from Canada, in 11 different speeches and press releases (http: //epw.senate.gov/public/index.cfm?FuseAction=Minority. Speeches). From quite a different standpoint, a World Wildlife Fund report (Norris et al., 2002) generalized the findings of declining polar bear body condition from
Western Hudson Bay to the entire Hudson Bay region (e.g., Norris et al., 2002:22), which encompasses two other separate populations for which little to no data existed at the time. However, since that report Obbard et al. (2006, 2007) have documented declining body condition in bears from the Southern Hudson Bay population as well.

So far, authoritative policy prescriptions have been promoted or invoked on the basis of specific bodies of intelligence, either scientific (e.g., PBSG resolutions, the IUCN listing) or TEK (Nunavut's IQ-based quota increase in 2005). No prescriptions have yet been developed that integrate disparate sources of information, although Nunavut's apparent intention to combine IQ with population surveys at 15 -year intervals may lead in this direction. Prescriptions such as the 2005 PBSG resolution subordinating TEK to science would likely be seen by many aboriginal people as exclusive and provocative (Berkes, 1999; Nadasdy, 2003; Diduck et al., 2005; White, 2006). Our assembled evidence suggests that intelligence, promotion, and prescription are being carried out in a disjointed and factionalized manner by participants who appear to be acting largely unilaterally. Coordination among institutional actors through bodies such as the PBTC and PBSG historically has been one of the hallmarks of polar bear management efforts (Prestrud and Stirling, 1994), so this breakdown is somewhat surprising. A possible explanation for that shift is that traditional venues for coordination are increasingly divisive, and so less effective at their primary function. As the value demands of participants (both institutions and the individuals representing them) conflict, and as promotional activities become increasingly competitive, the PBTC and PBSG may not provide enough effective mediation to create broadly supported prescriptions. For example, examination of PBSG meeting minutes reveals that the controversial 2005 resolution on science and TEK was the only resolution ever to require a vote-rather than consensus-since the PBSG began making resolutions in 1993. 


\section{Condition 3: Fragmented and Polarizing Social Process}

Social process configures the arena in which decisions are made. It is the aggregate suite of participants, their perspectives, myths, values, and employed strategies, together with resultant outcomes (Lasswell, 1971). Components of social process include participants (individuals, groups, organizations), perspectives (value demands, expectations, identities, myths), situations (organized or not, value-inclusive or exclusive, crisis or intercrisis), base values (positive and negative assets reckoned by power, enlightenment, wealth, well-being, skill, affection, respect, and rectitude), strategies (coercive, persuasive, communicative, collaborative), outcomes (proximate choices, deprivation or indulgence of base values), and effects (the long-term distribution of base values).

Identified weaknesses of the polar bear decision process are brought into sharp relief by features of the social process. Some insight into relevant dynamics of social process can be gained by examining the distributions of participants' base and scope values, which can be interpreted from the statements in Table 2 . The perspective of scientific management is being authoritatively invoked, largely by non-Inuit scientists and managers, in a manner that has provoked a strong negative reaction from representatives of, and advocates for, Inuit society. Enlightenment is invoked as a base value by all three scientists quoted, but each is invoking and applying his own particular form of enlightenment to support different and sometimes conflicting demands. Enlightenment is also used by the PBSG as a base for claiming power in the decision process, as seen clearly in its 2005 resolution on science and TEK. Contrastingly, Nunavut politicians are using rectitude as a base for claiming respect and well-being for their constituents, which would have the additional effect of enhancing their political power. The respect and wellbeing of Inuit is widely seen by the Nunavut Government and Inuit organizations as being at stake in this situation. A more inclusive approach was promoted by Nobel Peace Prize nominee Sheila Watt-Cloutier (2007), who attempted to move the public discourse beyond competing and exclusive value demands, invoking the values of rectitude, enlightenment, respect, and well-being.

Quotes summarized in Table 2 can also be examined for whether the implicit or explicit focus is on the structure and function of decision-making versus technical details of content. A strong, although incomplete, divide along these lines is evident between participants promoting the scientific management perspective, who tend to address content, versus promoters of other perspectives, who tend to focus on procedural questions, such as determining appropriate normative standards for decisions. This is perhaps not surprising, since participants whose value demands were not adversely affected by policy prescriptions would have no compelling need to consider anything but decision content, whereas those whose demands were affected would have a definite interest in opening up aspects of the decision process for discussion and possible change.

The Canadian polar bear management regime has traditionally privileged one particular myth-scientific management-and the closely related discourse of administrative rationalism. The regime is a hierarchical, vertically organized system where scientific information flows upward from the PBTC to the PBAC, and policy decisions flow downward from the PBAC to personnel within its participating government agencies, who then must apply those decisions (Berkes et al., 2005). This relationship has become strongly institutionalized over time as federal, territorial, and academic biologists systematically delineated and estimated polar bear populations, and developed, implemented, and refined a comprehensive and sophisticated harvest quota system (Taylor and Lee, 1995). The successful outcomes of this process likely reinforced the myth of scientific management within the regime (e.g., Fikkan et al., 1993), rendering at least some participating scientists and managers less capable of selfreflection. Overall, that reinforcement would have led to consolidation of epistemic communities and rigidification of institutional boundaries and decision processes (Diduck et al., 2005). A small number of individuals dominate discourse at all levels of the regime (Berkes et al., 2005), which tends to reduce the variety of perspectives expressed at the table and perpetuate established norms and beliefs.

Such a situation unfortunately reduces the likelihood of innovation and creativity, which are exactly the attributes required of a management system if it is to adapt successfully to novel challenges (Gunderson and Holling, 2002), precisely the sort of challenges that typify current polar bear conservation. Indeed, a call for creativity was a central part of Watt-Cloutier's (2007) message. Inuit governance appears to have been long based on civic order, on norms and practices arising from shared values such as respect, affection, and rectitude. Recently, Inuit have experienced a shift in governance from a structure based heavily on civic order to one increasingly emphasizing public order enforced by norms and sanctions and codified in land-claim agreements (Bankes, 2005). This more overtly power-based, publicorder governance has resulted in more rigid authority structures that may be less adaptive in the rapidly changing biophysical environment of the Arctic (Armitage and Clark, 2005). As social and ecological changes accelerate, decision processes that remain centralized and hierarchical are not likely to be sufficiently responsive, regardless of the perceived quality of information they use.

\section{CONCLUSIONS}

The status quo policy process is not producing outcomes desired by many participants, whether these outcomes are reckoned in terms of polar bear conservation or value exchanges among participants, and the trend seems to be towards continued degradation of the management 
regime. Changes are needed if polar bears are to be conserved in a civil, equitable, and durable manner. These changes would include reconstituting decision making to produce a reconfigured social process that fosters reconciliation of divergent demands arising from participants' varied perspectives about "the problem" of polar bear management. It is important to note that the existing polar bear management regime has strengths and advantages that could be built upon (Berkes et al., 2005), such as ready exchanges of biological information and a high degree of international cooperation. We suggest thoughtful reform would likely be a more effective means of fostering longterm conservation than would outright termination of existing institutions or decision processes.

\section{Some Policy Alternatives}

Alternatives can be divided roughly into measures with shorter- and longer-term effects on the polar bear policy process. There are a number of feasible short-term interventions that would enhance the management regime's capacity for learning and adaptation:

1. Intelligence-focused venues to build relationships across disciplines and backgrounds (e.g., a science-IQ workshop held in October 2006 at the University of Alberta; see http://www.ualberta.ca/ ccinst/CH/news.htm).

2. Appraisals to learn the applicable lessons from successes such as the Inuvialuit-Inupiat polar bear harvest agreement (Brower et al., 2002) and the integration of science and TEK in setting harvest quotas for grizzly bear (Ursus arctos) on the Yukon/NWT North Slope (Clark, 2007).

3. Knowledge co-production projects, such as local-scale efforts to mitigate bear-human conflicts (Clark et al., 2005 ) or to develop community-based monitoring programs (e.g., Parlee et al., 2005).

4. Structured exercises, such as a Q-method workshop (e.g., Mattson et al., 2006), to help participants find common ground, prevent further polarization, and identify areas of common interest that can be developed further.

In the longer term, divesting authority to local decisionmaking and decentralizing decision processes will likely be important to increasing the adaptive capacity of regional and local-scale management institutions (Brunner et al., 2005). Learning and support will likely still depend to some degree on cross-scale institutional linkages, which have proven beneficial in the past (Berkes et al., 2005). Fostering such learning would be an appropriate function for higher-level institutional structures such as the PBAC and PBSG. However, reallocating power and reconfiguring institutions will likely depend on re-shaping the epistemic premises of those currently having authority over polar bear conservation in Canada, from current assumptions of traditional scientific management to a more inclusive emphasis on interdisciplinary and cross-cultural knowledge (Berkes et al., 2005; Brunner et al., 2005). Eventually, it may also become necessary to re-evaluate the 1973 Agreement's insistence on science-based management as the only means of conserving polar bears.

Such changes would require opening up existing decision processes to different voices, largely the aboriginal voices that have been marginalized in the polar bear management discourse to date (Berkes et al., 2005; Diduck et al., 2005). This goal can be accomplished by broadening disciplinary perspectives, promoting interdisciplinary projects, and further diversifying the distribution of authority. If these steps prove impractical within the confines of the PBTC, perhaps another body could be created to provide TEK-based perspectives to the PBAC and PBSG. The polar bear management system has in the past proven itself able to incorporate such self-organizing horizontal linkages among user groups into its predominantly vertical structure (Berkes et al., 2005), so this step might not be infeasible or even too unwieldy.

Even with such measures, however, significant challenges would remain. Despite widespread recognition that aboriginal input needs to be incorporated into polar bear management (Berkes et al., 2005), deepening conflicts over provocative policy prescriptions and the legitimacy of knowledge sources complicate this task. Cultural conflicts may be difficult to resolve, but failure of the institutions involved to attempt resolution could have dire consequences. Efforts to restructure decision processes and reconcile stakeholders are underway, and these efforts warrant support and encouragement if improving social process is a priority. The politicization of polar bears as a symbol will no doubt continue. If participants in polar bear management are to change this trend, they will need to accept that the established, comfortable, and relatively conflict-free scientific management regime is fundamentally changing and is unlikely to revert to its past state. This need not mean a descent into anarchy; the regime has ample intellectual, cultural, social, and financial resources for renewal. Whatever new form ultimately emerges, much of its activity will likely focus on reconciling diverging perspectives and contested problem definitions.

Reconciliation doesn't necessarily mean harmonizing fundamentally different perspectives. More plausibly, reconciliation entails providing a venue where competing problem definitions can be promoted and negotiated from a variety of perspectives, with uncertainties and underlying doctrinal assumptions discussed equitably and respectfully. Decision processes would thus require paying as much attention to instituting civil and equitable procedures as is currently paid to the content of decisions. Different forms of knowledge can be brought together within such a decision process, but the emphasis would ideally be as much on constructing a discourse that featured values, stakes, and uncertainties as on simply producing an integrated knowledge product (Clark and Slocombe, 2005). While such a re-invigorated discourse 
may not sound like an appealing goal compared to authoritative scientific reports and explicitly quantitative conservation prescriptions, it would be much more resilient to the shocks of symbolic politics that currently characterize the polar bear conservation policy process.

This paper presents a problem definition that aims to be comprehensive, yet is necessarily preliminary and provisional. It reflects our understanding of a rapidly evolving situation at a specific point in time from our collective standpoint as researchers with a policy orientation (Brunner and Willard, 2003). Further crucial steps towards improving our understanding of polar bear conservation policy would include more detailed analyses of relevant social and decision processes. The interlinking of regional processes (especially in the high-profile and conflicted Western Hudson Bay region) and international processes such as the recent "threatened" listing by the United States is particularly important. Polar bear conservation in the $21 \mathrm{st}$ century has become a "wicked" problem (Rittel and Webber, 1973; Nie, 2003): it is evolving quickly as ecological changes appear, social changes continue, and new information from different sources becomes available ever more rapidly. Achieving the ecological and social goals articulated in the 1973 Agreement will become an increasingly difficult challenge.

\section{ACKNOWLEDGEMENTS}

Support for this work came from the Social Sciences and Humanities Research Council of Canada, ArcticNet project 4.6, Conservation Hunting in the Arctic: An Analysis of Constraints and Opportunities, and Yukon College. We are especially grateful for considerable assistance from David Mattson, as well as comments by David Cherney and Mike Gibeau, all of which substantially improved the quality of this manuscript. The Policy Sciences 2006 Annual Institute provided a stimulating venue in which to pursue the development of these ideas.

\section{APPENDIX 1: POLAR BEAR CONSERVATION GOALS AND PROVISIONS FROM THE 1973 INTERNATIONAL AGREEMENT ON THE CONSERVATION OF POLAR BEARS AND THEIR HABITAT (PBSG, 1973)}

Article II: “ “...protect the ecosystems of which polar bears are a part, with special attention to habitat components such as denning and feeding sites and migration patterns, and shall manage polar bear populations in accordance with sound conservation practices based on the best available scientific data."

Article III: “... any Contracting Party may allow the taking of polar bears when such taking is carried out:... d) by local people using traditional methods in the exercise of their traditional rights and in accordance with the laws of that Party..."

\section{REFERENCES}

ACIA (ARCTIC CLIMATE IMPACT ASSESSMENT). 2004. Impacts of a warming Arctic. Cambridge: Cambridge University Press. http://www.amap.no/acia/.

AHDR. 2004. Arctic human development report. Akureyri, Iceland: Stefansson Arctic Institute. http://www.svs.is/AHDR/.

AMSTRUP, S.C., STIRLING, I., SMITH, T.S., PERHAM, C., and THIEMANN, G.W. 2006. Recent observations of intraspecfic predation and cannibalism among polar bears in the southern Beaufort Sea. Polar Biology 29(11):997-1002.

ARMITAGE, D., and CLARK, D. 2005. Issues, priorities, and research directions for oceans management in Canada's North. In: Berkes, F., Huebert, R., Fast, H., Manseau, M., and Diduck, A., eds. Breaking ice: Renewable resource and ocean management in the Canadian North. Northern Lights Series No. 7. Calgary: University of Calgary Press and Arctic Institute of North America. 337-362.

BANKES, N. 2005. Exploring the roles of law and hierarchy in ideas of resilience: Regulating resource harvesting in Nunavut. In: Berkes, F., Huebert, R., Fast, H., Manseau, M., and Diduck, A., eds. Breaking ice: Renewable resource and ocean management in the Canadian North. Northern Lights Series No. 7. Calgary: University of Calgary Press and Arctic Institute of North America. 291-311.

BERKES, F. 1999. Sacred ecology: Traditional ecological knowledge and resource management. Philadelphia, Pennsylvania: Taylor and Francis.

BERKES, F., BANKES, N., MARSCHKE, M., ARMITAGE, D., and CLARK, D. 2005. Cross-scale institutions and building resilience in the Canadian North. In: Berkes, F., Huebert, R., Fast, H., Manseau, M., and Diduck, A., eds. Breaking ice: Renewable resource and ocean management in the Canadian North. Northern Lights Series No. 7. Calgary: University of Calgary Press and Arctic Institute of North America. 225-248.

BERTEAUX, D., HUMPHRIES, M.M., KREBS, C.J., LIMA, M., McADAM, A.G., PETTORELLI, N., RÉALE, D., SAITOH, T., TKLADEC, E., WELADJI, R.B., and STENSETH, N.C. 2006. Constraints to projecting the effects of climate change on mammals. Climate Research 32:151-158.

BROOK, R.K., and McLACHLAN, S.M. 2005. On using expertbased science to "test" local ecological knowledge. Ecology and Society 10(2): r3. [online] URL: http://www.ecologyand society. org/vol10/iss2/resp3/.

BROWER, C.D., CARPENTER, A., BRANIGAN, M.L., CALVERT, W., EVANS, T., FISCHBACH, A.S., NAGY, J.A., SCHLIEBE, S., and STIRLING, I. 2002. The Polar Bear Management Agreement for the Southern Beaufort Sea: An evaluation of the first ten years of a unique conservation agreement. Arctic 55(4):362-372.

BRUNNER, R.D., and WILLARD, A. 2003. Professional insecurities: A guide to understanding and career management. Policy Sciences 36:3-36.

BRUNNER, R.D., STEELMAN, T.A., COE-JUELL, L., CROMLEY, C.M., EDWARDS, C.M., and TUCKER, D.W. 2005. Adaptive governance: Integrating science, policy, and decision-making. New York: Columbia University Press. 
CBC (CANADIAN BROADCASTING CORPORATION). 2006. Canada's polar bear sport hunt not targeted: Environmental groups. November 15. http://www.cbc.ca/canada/north/story/ 2006/11/15/polar-hunt.html.

CENTER FOR BIOLOGICAL DIVERSITY. 2005. Before the Secretary of the Interior: Petition to list the polar bear (Ursus maritimus) as a threatened species under the Endangered Species Act. http://www.biologicaldiversity.org/species/mammals/ polar_bear/index.html.

CLARK, D. 2003. Polar bear-human interactions in Canadian national parks, 1986-2000. Ursus 14:65-71.

- 2007. Local and regional-scale societal dynamics in grizzly bear conservation. $\mathrm{PhD}$ thesis, Wilfrid Laurier University, Waterloo, Ontario.

CLARK, D., and SLOCOMBE, D.S. 2005. Re-negotiating science in protected areas: Grizzly bear conservation in the southwest Yukon. In: Humphrys, G., and Williams, M., eds. Presenting and representing environments. Dordrecht, Netherlands: Springer. 33-53.

CLARK, T.W. 2002. The policy process: A practical guide for natural resource professionals. New Haven, Connecticut: Yale University Press.

CLARK, T.W., BACKHOUSE, G.N., and READING, R.P. 1995. Prototyping in endangered species recovery programmes: The case of the eastern barred bandicoot experience. In: Bennett, A., Backhouse, G.N., and Clark, T.W., eds. People and nature conservation: Perspectives on private land use and endangered species recovery. Mosman, N.S.W.: Transactions of the Royal Zoological Society of New South Wales. 50-62.

CLARK, T.W., CASEY, D., and HALVERSON, A., eds. 2000a. Developing sustainable management policy for the National Elk Refuge. Yale School of Forestry and Environmental Studies Bulletin No. 104.

CLARK, T.W., MAZUR, N., CORK, S., DOVERS, S., and HARDING, R. 2000b. The koala conservation policy process: An appraisal and recommendations. Conservation Biology 14(3):691-701.

CLARK, T.W., RUTHERFORD, M.B., and CASEY, D., eds. 2005. Coexisting with large carnivores: Lessons from Greater Yellowstone. Washington, D.C.: Island Press.

DeMASTER, D.P., and STIRLING, I. 1981. Ursus maritimus. Mammalian Species 145. 7 p.

DEROCHER, A.E., LUNN, N.J., and STIRLING, I. 2004. Polar bears in a warming climate. Integrative and Comparative Biology 44:163- 176.

DIDUCK, A., BANKES, N., CLARK, D., and ARMITAGE, D. 2005. Unpacking social learning in social-ecological systems: Case studies of polar bear and narwhal management in northern Canada. In: Berkes, F., Huebert, R., Fast, H., Manseau, M., and Diduck, A., eds. Breaking ice: Renewable resource and ocean management in the Canadian North. Northern Lights Series No. 7. Calgary: University of Calgary Press and Arctic Institute of North America. 269-290.

DOWSLEY, M., and WENZEL, G. 2008. "The time of the most polar bears": A co-management conflict in Nunavut. Arctic 61(2):177-189.
DRYZEK, J.S. 1997. The politics of the earth: Environmental discourses. Oxford: Oxford University Press.

DYCK, M.G., SOON, W., BAYDACK, R.K., LEGATES, D.R., BALIUNAS, S., BALL, T.F., and HANCOCK, L.O. 2007. Polar bears of western Hudson Bay and climate change: Are warming spring air temperatures the "ultimate" control factor? Ecological Complexity 4(3):73-84.

FIKKAN, A., OSHERENKO, G., and ARIKAINEN, A. 1993. Polar bears: The importance of simplicity. In Young, O.R., and Osherenko, G., eds. Polar politics: Creating international environmental regimes. Ithaca, New York: Cornell University Press. $96-151$.

FOOTE, L. 2007. Testimony to the U.S. Senate Committee on Environment \& Public Works. Subcommittee Hearing on "Global Warming and Wildlife," Wednesday February 7, 2007. http:// epw.senate.gov/public/index.cfm?FuseAction=Hearings. Testimony\&Hearing_ID=7efcd166-802a-23ad-4634-25057d9d 08bf\&Witness_ID=5924b692-92ae-4437-9bd8-3482a55 e0b94.

FORD, J., PEARCE, T., SMIT, B., WANDEL, J., ALLURUT, M., SHAPPA, K., ITTUSUJURAT, H., and QRUNNUT, K. 2007. Reducing vulnerability to climate change in the Arctic: The case of Nunavut, Canada. Arctic 60(2):150-166.

FREEMAN, M.M.R., and WENZEL, G.W. 2006. The nature and significance of polar bear conservation hunting in the Canadian Arctic. Arctic 59(1):21-30.

GEORGE, J. 2005. Nunavut IQ on polar bears not documented. Nunatsiaq News, August 5.

GILCHRIST, G., MALLORY, M., and MERKEL, F. 2005. Can local ecological knowledge contribute to wildlife management? Case studies of migratory birds. Ecology and Society 10(1): 20. [online] URL: http://www.ecologyandsociety.org/vol10/iss1/ $\operatorname{art} 20 \%$.

GUNDERSON, L., and HOLLING, C.S., eds. 2002. Panarchy: Understanding transformations in human and natural systems. Washington, D.C.: Island Press.

HEALY, R.G., and ASCHER, W. 1995. Knowledge in the policy process: Incorporating new environmental information in natural resources policymaking. Policy Sciences 28:1-19.

HOLLAND, M.M., BITZ, C.M., and TREMBLAY, B. 2006. Future abrupt reductions in the summer Arctic sea ice. Geophysical Research Letters 33, L23503, doi:10.1029/2006GL0 28024.

HOLLING, C.S., and MEFFE, G.K. 1996. Command and control and the pathology of natural resource management. Conservation Biology 10:328-337.

HOWARD, A., and WIDDOWSON, F. 1996. Traditional knowledge threatens environmental assessment. Policy Options 17(9): $34-36$.

INAC (INDIAN AND NORTHERN AFFAIRS CANADA). 1984. The Western Arctic Claim - The Inuvialuit Final Agreement. Ottawa: INAC. http://www.ainc-inac.gc.ca/pr/agr/inu/wesar _e.html.

INDIAN AND NORTHERN AFFAIRS CANADA and TUNGAVIK FEDERATION OF NUNAVUT. 1993. Agreement Between The Inuit of the Nunavut Settlement Area and Her Majesty The Queen in Right of Canada. Ottawa: INAC. http:// www.ainc-inac.gc.ca/pr/agr/nunavut/index_e.html. 
INHOFE, J. 2006. Hot and cold media spin cycle: A challenge to journalists who cover global warming. A skeptic's guide to debunking global warming alarmism. www.epw.senate.gov/ public/index.cfm?FuseAction=Minority.Blogs.

IPCC (INTERGOVERNMENTAL PANEL ON CLIMATE CHANGE). 2007. Climate change 2007: The physical science basis. Contribution of Working Group I to the Fourth Assessment Report of IPCC. http://www.ipcc.ch/ipcc reports/ar4-wg1.htm/. JOHNSON, C. 2002. Polar bear co-management in Alaska: Cooperative management between the US Fish and Wildlife Service and the native hunters of Alaska for the conservation of polar bears. In: Lunn, N.J., Schliebe, S., and Born, E., eds. Polar bears. Proceedings of the 13th Working Meeting of the IUCN/SSC Polar Bear Specialist Group. Occasional Paper of the IUCN Species Survival Commission No. 26. Gland, Switzerland: International Union for Conservation of Nature and Natural Resources. 139-141.

KEITH, D., ARQVIQ, J., KAMOOKAK, L., AMERALIK, J., and the GJOA HAVEN HUNTERS' AND TRAPPERS' ORGANIZATION. 2005. Inuit qaujimaningit nanurnut: Inuit knowledge of polar bears. Solstice Series No. 4. Edmonton, Alberta: Canadian Circumpolar Institute Press.

KREBS, C.J., and BERTEAUX, D. 2006. Problems and pitfalls in relating climate variability to population dynamics. Climate Research 32:143-149.

LASSWELL, H.D. 1970. The emerging conception of the policy sciences. Policy Sciences 1:3-14.

1971. A pre-view of the policy sciences. New York: Elsevier.

LASSWELL, H.D., and McDOUGAL, M.S. 1992. Jurisprudence for a free society: Studies in law, science and politics. New Haven, Connecticut: New Haven Press.

LUDWIG, D. 2001. The era of management is over. Ecosystems $4: 758-764$.

LUDWIG, D., HILBORN, R., and WALTERS, C. 1993. Uncertainty, resource exploitation and conservation: Lessons from history. Science 260:17-36.

LUDWIG, D., MANGEL, M., and HADDAD, B. 2001. Ecology, conservation and public policy. Annual Review of Ecology and Systematics 32:481-517.

MANSEAU, M., PARLEE, B., and AYLES, G.B. 2005. A place for traditional ecological knowledge in resource management. In: Berkes, F., Huebert, R., Fast, H., Manseau, M., and Diduck, A., eds. Breaking ice: Renewable resource and ocean management in the Canadian North. Northern Lights Series No. 7. Calgary: University of Calgary Press and Arctic Institute of North America. 141-164.

MARINE MAMMAL COMMISSION. 2007. Letter from Timothy J. Ragen, Executive Director, to Rosa Meehan, Supervisor, Marine Mammals Management, U.S. Fish and Wildlife Service, Anchorage, AK, dated April 9, 2007, re: Comments and recommendations regarding a 12-month petition finding and proposed rule to list the polar bear under provisions of the Endangered Species Act (ESA) as a threatened species throughout its range. http://www.mmc.gov/letters/letters.html\#040907.

MATTSON, D.J., BYRD, K.L., RUTHERFORD, M.B., BROWN, S.R., and CLARK, T.W. 2006. Finding common ground in large carnivore conservation: Mapping contending perspectives. Environmental Science and Policy 9:392-405.

MENZIES, C.R., ed. 2006. Traditional ecological knowledge and natural resource management. Lincoln: University of Nebraska Press.

MILES, M.B., and HUBERMAN, A.M. 1994. Qualitative data analysis, an expanded sourcebook, 2nd ed. Thousand Oaks, California: Sage Publications.

MONBIOT, G. 2006. Heat: How to stop the planet from burning. Toronto, Ontario: Doubleday Canada.

NADASDY, P. 2003. Hunters and bureaucrats: Power, knowledge, and aboriginal-state relations in the southwest Yukon. Vancouver: University of British Columbia Press.

- 2006. The case of the missing sheep: Time, space and the politics of "trust" in co-management practice. In: Menzies, C.R., ed. 2006. Traditional ecological knowledge and natural resource management. Lincoln: University of Nebraska Press. 127-152.

NATCHER, D.C., DAVIS, S., and HICKEY, C.G. 2005. Comanagement: Managing relationships, not resources. Human Organization 64:240-250.

NIE, M. 2003. Drivers of natural resource-based political conflict. Policy Sciences 36:307-341.

NORRIS, S., ROSENTRATER, L., and EID, P.M. 2002. Polar bears at risk: A WWF status report. Oslo, Norway: World Wildlife Fund International Arctic Program.

OBBARD, M.E., CATTET, M.R.L., MOODY, T., WALTON, L.R., POTTER, D., INGLIS, J., and CHENIER, C. 2006. Temporal trends in the body condition of southern Hudson Bay polar bears. Climate Change Research Information Note 3 . Peterborough: Ontario Ministry of Natural Resources.

OBBARD, M.E., McDONALD, T.L., HOWE, E.J., REGEHR, E.V., and RICHARDSON, E.S. 2007. Polar bear population status in southern Hudson Bay, Canada., USGS Science Strategy to Support U.S. Fish and Wildlife Service Polar Bear Listing Decision, Administrative Report. Reston, Virginia: U.S. Department of the Interior, U.S. Geological Survey. 36 p.

OVERPECK, J.T., STURM, M., FRANCIS, J.A., PEROVICH, D.K., SERREZE, M.C., BENNER, R., CARMACK, E.C., CHAPIN, F.S., III, GERLACH, S.C., HAMILTON, L.C., HINZMAN, L.D., HOLLAND, M., HUNTINGTON, H.P., KEY, J.R., LLOYD, A.H., MACDONALD, G.M., McFADDEN, J., NOONE, D., PROWSE, T.D., SCHLOSSER, P., and VÖRÖSMARTY, C. 2005. Arctic system on trajectory to new, seasonally ice-free state. EOS 86(34), doi:10.1029/2005EO 340001.

PARLEE, B., MANSEAU, M., and LUTSEL K'E DENE FIRST NATION. 2005. Understanding and communicating about ecological change: Denesoline indicators of ecosystem health. In: Berkes, F., Huebert, R., Fast, H., Manseau, M., and Diduck, A., eds. Breaking ice: Renewable resource and ocean management in the Canadian North. Northern Lights Series No. 7. Calgary: University of Calgary Press and Arctic Institute of North America. 165-182.

PBSG (IUCN/SSC POLAR BEAR SPECIALIST GROUP). 1973. Agreement on the conservation of polar bears. Oslo: PBSG. http://pbsg.npolar.no/ConvAgree/agreement.htm. 
2005. Resolutions from the 14th Meeting of the PBSG in Seattle, USA, 2005. http://pbsg.npolar.no.

PRESTRUD, P., and STIRLING, I. 1994. The International Polar Bear Agreement and the current status of polar bear conservation. Aquatic Mammals 20(3):113-124.

REGEHR, E.V., AMSTRUP, S.C., and STIRLING, I. 2006. Polar bear population status in the southern Beaufort Sea. USGS Open-File Report 2006-1337. Reston, Virginia: U.S. Department of the Interior, U.S. Geological Survey. 30 p.

REGEHR, E.V., LUNN, N.J., AMSTRUP, S.C., and STIRLING, I. 2007. Effects of earlier sea ice breakup on survival and population size of polar bears in western Hudson Bay. Journal of Wildlife Management 71(8):2673-2683.

RITTEL, H.J.W., and WEBBER, M.M. 1973. Dilemmas in a general theory of planning. Policy Sciences 4:155-169.

ROSS, K. 2000. Environmental conflict in Alaska. Boulder: University of Colorado Press.

RUTHERFORD, M.B., and CLARK, T.W. 2005. Coexisting with large carnivores: Lessons from Greater Yellowstone. In: Clark, T.W., Rutherford, M.R., and Casey, D., eds. Coexisting with large carnivores: Lessons from Greater Yellowstone. Washington, D.C.: Island Press. 254-270.

SIEGEL, K. 2007. Flock of Siegel: Kassie Siegel from the Center for Biological Diversity answers Grist's questions, January 15, 2007. http://www.grist.org/comments/interactivist/2007/01/15/ siegel/index.html.

STATE OF ALASKA. 2007. Letter from Governor Sarah Palin, Governor of the State of Alaska, dated April 09, 2007, to Dirk Kempthorne, Secretary of the Interior, ATTN: polar bear finding, plus enclosures. http://www.adfg.state.ak.us/special/esa/ polarbears/state_comments4-9-07.pdf.

STEVENSON, M.G. 2006.The possibility of difference: Rethinking co-management. Human Organization 65(2):167-180.

STIRLING, I. 1988. Polar bears. Ann Arbor: University of Michigan Press.

STIRLING, I., and DEROCHER, A.E. 1993. Possible impacts of climate warming on polar bears. Arctic 46(3):240-245.

STIRLING, I., and PARKINSON, C. 2006. Possible effects of climate warming on selected populations of polar bears (Ursus maritimus) in the Canadian Arctic. Arctic 59(3):261-275.

STIRLING, I., LUNN, N.J., and IACOZZA, J. 1999. Long-term trends in the population ecology of polar bears in western Hudson Bay in relation to climatic change. Arctic 52(3): 294-306.
TAYLOR, M.K., and LEE, J. 1995. Distribution and abundance of Canadian polar bear populations: A management perspective. Arctic 48(2):147-154.

TRESEDER, L., HONDA-McNEIL, J., BERKES, M., BERKES, F., DRAGON, J., NOTZKE, C., SCHRAMM, T., and HUDSON, R.J. 1999. Northern Eden: Community-based wildlife management in Canada. Occasional Paper 46. Edmonton, Alberta: Canadian Circumpolar Institute.

TURNER, N., and CLIFTON, H. 2006. The forest and the seaweed: Gitga'at seaweed, traditional ecological knowledge, and community survival. In: Menzies, C.R., ed. 2006. Traditional ecological knowledge and natural resource management. Lincoln: University of Nebraska Press. 65-86.

TYRRELL, M. 2007. More bears, less bears: Inuit and scientific perceptions of polar bear populations on the west coast of Hudson Bay. Etudes Inuit Studies 30(2):191-208.

USFWS (U.S. FISH AND WILDLIFE SERVICE). 2007. Endangered and threatened wildlife and plants; 12 -month petition finding and proposed rule to list polar bear (Ursus maritimus) as threatened throughout its range; proposed rule. Federal Register 72(5): 1063 - 1099 .

- 2008. Endangered and threatened wildlife and plants; determination of threatened status for the polar bear (Ursus maritimus) throughout its range; final rule. Federal Register 73(95):28212-28303.

WATSON, A., ALESSA, L., and GLASPELL, B. 2003. The relationship between traditional ecological knowledge, evolving cultures, and wilderness protection in the circumpolar North. Conservation Ecology 8(1), 2. [online] URL: http://www.cons ecol.org/vol8/iss 1/art2.

WATT-CLOUTIER, S. 2007. Nunavut must think big, not small, on polar bears. Nunatsiaq News, January 19.

WENZEL, G. 1991. Animal rights, human rights: Ecology, economy, and ideology in the Canadian Arctic. Toronto, Ontario: University of Toronto Press.

. 2004. From TEK to IQ: Inuit qaujimajatuqangit and Inuit cultural ecology. Arctic Anthropology 41:238-250.

WHITE, G. 2006. Cultures in collision: Traditional knowledge and Euro-Canadian governance processes in northern land-claim boards. Arctic 59(4):401-414.

YIN, R.K. 2003. Case study research: Design and methods, 3rd ed. Thousand Oaks, California: Sage Publications,

YOUNG, O.R. 1992. Arctic politics: Conflict and cooperation in the circumpolar North. Hanover, New Hampshire: University Press of New England. 